\title{
APLIKASI DATA PENGINDERAAN JAUH DAN SISTEM INFORMASI GEOGRAFI (SIG) DALAM PEMILIHAN TAPAK POTENSIAL PLTN KALIMANTAN BARAT
}

\author{
Heni Susiati, Yarianto SBS., Kurnia Anzhar, Bansyah Kironi, dan June Mellawati \\ Pusat Kajian Sistem Energi Nuklir (PKSEN) BATAN \\ Jalan Kuningan Barat, Mampang Prapatan, Jakarta 12710 \\ Telp/Fax: 021 5204243, E-mail: heni susiati@batan.go.id
}

\begin{tabular}{|c|c|c|}
\hline Diterima & Diterima dalam bentuk revisi & Disetujui \\
\hline 29 Juli 2015 & 10 Nopember 2015 & 25 Nopember 2015 \\
\hline
\end{tabular}

\begin{abstract}
ABSTRAK
APLIKASI DATA PENGINDERAAN JAUH DAN SISTEM INFORMASI GEOGRAFI (SIG) DALAM PEMILIHAN TAPAK POTENSIAL PLTN KALIMANTAN BARAT. Pemilihan tapak potensial PLTN berbasis spasial yang diaplikasikan di sepanjang pesisir daerah Kalimantan Barat telah dilakukan dengan menambahkan beberapa kriteria terhadap kriteria yang digunakan pada penelitian tahun 2014. Tujuan penelitian adalah untuk mendapatkan lokasi tapak potensial untuk PLTN di wilayah pesisir Provinsi Kalimantan Barat berdasarkan kriteria yang berlaku. Metode penelitian meliputi pengumpulan data primer, interpretasi data penginderaan jauh dan analisis pemeringkatan berbasis sistem informasi geografi. Hasil penelitian diperoleh 6 tapak potensial untuk lokasi PLTN, yaitu Desa Air Besar Kecamatan Kendawangan Kabupaten Ketapang (peringkat pertama), Desa Sie Kecamatan Simpang Hilir Kabupaten Kayong (peringkat kedua), Desa Sungai Kanan, Kecamatan Muara, Kabupaten Ketapang (peringkat ketiga), Desa Sungai Nanjung Kecamatan Matan Kabupaten Ketapang (peringkat keempat), Desa Kendawangan Kanan, Kecamatan Kendawangan Kabupaten Ketapang (peringkat kelima) dan Desa Sungai Nanjung Kecamatan Matan kabupaten Ketapang, Desa Matang Kecamatan Paloh, Kabupaten Sambas (peringkat keenam). Analisis kesesuaian lahan menunjukkan bahwa semua tapak potensial tersebut telah memenuhi kriteria umum dan khusus, antara lain karena bukan merupakan lahan gambut, serta jauh dari pemukiman.
\end{abstract}

Kata kunci: tapak potensial, PLTN, Penginderaan Jauh, SIG, sesuai

\begin{abstract}
APPLICATION OF REMOTE SENSING DATA AND GEOGRAPHIC INFORMATION SYSTEM (GIS) IN THE SELECTION OF A NPP POTENTIAL SITE IN WEST KALIMANTAN. Potential site selection on spatial basis which applied throughout the coast of West Kalimantan has been performed by adding additional criteria compare to the criteria used in 2014. The objective of research is to get the potential site of nuclear power plants (NPP) in the coastal areas of West Kalimantan Province based on the aplicable criteria. Research methods include collecting of primary data, interpretation of remote sensing data, and weighting analysis based on SIG. The research results obtained sixs of potential site for NPP, ie., Air Besar Village Kendawangan Subdistrict Ketapang Regency (first rank), Sie Village Simpang Hilir Subdistrict Kayong Regency (second rank), Sungai Kanan Village Muara Subdistrict Ketapang Regency (third rank), Sungai Nanjung Village Matan Subdustrict Ketapang Regency (fourth rank), Kendawangan Kanan Village Kendawangan Subdistrict Ketapang Regency (fifth rank) dan Sungai Nanjung Village Matan Subdistrict Ketapang Regency, Matang Village Paloh Subdistrict, Sambas Regency (sixth rank). Analysis of land suitability showed that all potential has met the general and specific criteria, among other things because it is not a peat and far away from the settlements.
\end{abstract}

Keywords: potential site, NPP, Remote Sensing, GIS, matching 


\section{PENDAHULUAN}

Pembangunan wilayah pesisir di Kalimantan Barat menghadapi tantangan mendasar berkaitan dengan rencana pengembangan industri di daerah tersebut. Selain tantangan terkait karakteristik sosial ekonomi, sumber daya alam, juga termasuk tantangan terhadap ketersedian listrik ${ }^{[1]}$. Dalam RPJMD (Rencana Pembangunan Jangka Menengah Daerah) Provinsi Kalimantan Barat tahun 2013-2018, PLTN (Pembangkit Listrik Tenaga Nuklir) sebagai salah satu jenis teknologi pembangkit listrik telah dimasukkan sebagai sumber energi baru dan energi terbarukan (EBT) untuk dapat memenuhi kebutuhan listrik di wilayah tersebut ${ }^{2]}$. Untuk mempersiapkan program PLTN di Kalimantan Barat, telah dilakukan kegiatan survei awal untuk inventarisasi potensi tapak PLTN di pesisir Provinsi Kalimantan Barat. Kegiatan inventarisasi tapak potensial PLTN di wilayah pesisir telah dilakukan secara bertahap mulai akhir tahun 2013 sampai sekarang. Berdasarkan hasil penelitian pada tahun 2014 diperoleh 4 tapak potensial PLTN yaitu di Kecamatan Kendawangan, Sukadana, Matan Hilir Utara dan Matan Hilir Selatan[ ${ }^{[3]}$. Penentuan tapak potensial tersebut ditentukan menggunakan metode pemeringkatan berdasarkan kriteria kemiringan lereng, litologi, geologi, topografi, curah hujan, kerawanan bencana, jarak ke badan air, posisi daerah pemukiman, tataguna lahan, lahan gambut, hidrogeologi, dan lainlain[3].

Pemilihan tapak PLTN dilakukan sebagai tahap awal dalam program PLTN dan harus mengacu pada kriteria yang telah ditetapkan oleh BAPETEN maupun IAEA ${ }^{[4-6] .}$ Dalam pedoman IAEA disebutkan bahwa tapak-tapak potensial yang didapatkan pada tahap analisis regional, kemudian ditapis menggunakan karakteristik tambahan yang belum dipertimbangkan dalam tahap analisis regional dengan menggunakan kriteria yang lebih rinci. Sesuai dengan azas keselamatan teknologi nuklir, maka pemilihan lokasi (site) untuk PLTN harus memenuhi berbagai syarat keselamatan[5,6]. Demikian juga dengan ketentuan keselamatan evaluasi tapak reaktor nuklir oleh BAPETEN ${ }^{[4]}$.

Tujuan penelitian adalah untuk mendapatkan tapak potensial di daerah studi sepanjang pesisir provinsi Kalimantan Barat, yang meliputi kabupaten Sambas, Bengkayang, Kubu Raya, Pontianak, Kayong Utara, dan Ketapang berbasis spasial dengan menambahkan beberapa kriteria terhadap kriteria yang digunakan pada penelitian sebelumnya (tahun 2014). Pada tahap awal telah dilakukan inventarisasi tapak potensial yang ada di wilayah penelitian di kabupaten Ketapang dan Kayong Utara ${ }^{[2]}$. Tahap berikutnya adalah penapisan (screening) yaitu kajian tapak-tapak potensial secara lebih rinci (melalui kegiatan survei, sampling, data sekunder rinci) sepanjang pesisir Provinsi Kalimantan Barat untuk mendapatkan tapak kandidat terseleksi (selected candidate sites). Tahap terakhir yaitu pembandingan dan pemeringkatan dilakukan untuk mendapatkan tapak kandidat terpilih (preferred candidate site) ${ }^{[6]}$. Aplikasi Sistem Informasi Geografi (SIG) sangat besar perannya dalam penentuan tapak potensial, karena aspek yang ditinjau dalam pemilihan tapak cukup banyak dan sangat tergantung pada data spasial. Hasil penelitian ini diharapkan dapat menjadi masukan bagi para pemangku kepentingan dalam menentukan tapak potensial PLTN.

\section{METODOLOGI PENELITIAN}

\subsection{Analisis Topikal}

Kegiatan tiap aspek studi meliputi pengumpulan, pengolahan, penyusunan database untuk mendapatkan informasi dan karakteristik tentang aspek yang diteliti. Zonasi bahaya dilakukan dengan penetapan kriteria terlebih dahulu untuk setiap aspek, kemudian dibuat buffering. 


\subsection{Analisis Terpadu}

Analisis terpadu pada hakekatnya adalah integrasi berbagai hasil kegiatan topikal yang bertujuan untuk mengetahui keterkaitan dan pengaruhnya terhadap penetapan tapaktapak potensial. Dalam hal ini, hasil analisis setiap aspek mengenai zona keselamatan dan zona bahaya yang dituangkan dalam sistem informasi geografi diintegrasikan secara sistematis, sesuai pengelompokan topikal studi tapak PLTN.

\subsection{Kriteria Penilaian}

Kriteria penilaian yang digunakan untuk evaluasi tapak potensial meliputi kriteria umum dan kriteria khusus. Kriteria umum disesuaikan berdasarkan kondisi regional dan persyaratan umum, sedangkan kriteria khusus untuk setiap topik mengacu pada pedoman internasional (IAEA, USNRC-Amerika Serikat, NSC-Jepang dll.), peraturan nasional, peraturan daerah, diskusi dengan expert dan ditetapkan berdasarkan kesepakatan tenaga ahli.

\subsection{Pemilihan Tapak Potensial PLTN Menggunakan ArcGis}

Analisis kesesuaian lahan tapak PLTN menggunakan beberapa parameter kesesuaian lahan. Pemodelan kesesuaian lahan tapak PLTN dilakukan dengan metode skoring dan matching faktor. Skoring dilakukan pada parameter-parameter sehingga menghasilkan kesesuaian lahan tapak PLTN tahap pertama sedangkan pada tahap kedua digunakan metode matching melalui parameter zonasi lahan permukiman, pola ruang dan lahan gambut.

\subsubsection{Peralatan}

1. Arc GIS 10.2

2. Global Mapper 10

2.4.2. Bahan

1. Peta Rupa Bumi Indonesia (RBI)

2. Peta Geologi

3. DEM SRTM (Digital Elevation Model) (Shuttle Radar Topographic Mission)

4. Peta Hidrogeologi

5. Peta Kawasan Hutan

6. Peta Lahan Gambut

7. Citra Satelit SPOT 6 dan 7

2.4.3. Tahap Pembuatan Peta Parameter dan Tahap Skoring \& Pembobotan Kesesuaian Lahan Tapak PLTN

Pemodelan analisis kesesuaian lahan tapak PLTN dilakukan dengan tahapan pembuatan peta setiap parameter pengaruh potensi tapak PLTN, seperti Peta Struktur Geologi, Peta Litologi, Peta Morfologi, Peta Hidrogeologi, Peta HIE (Human Induced Event), Peta Penggunaan Lahan, Peta Zonasi Pemukiman, Peta Lahan Gambut dan Peta Pola Ruang Kalimantan Barat. 

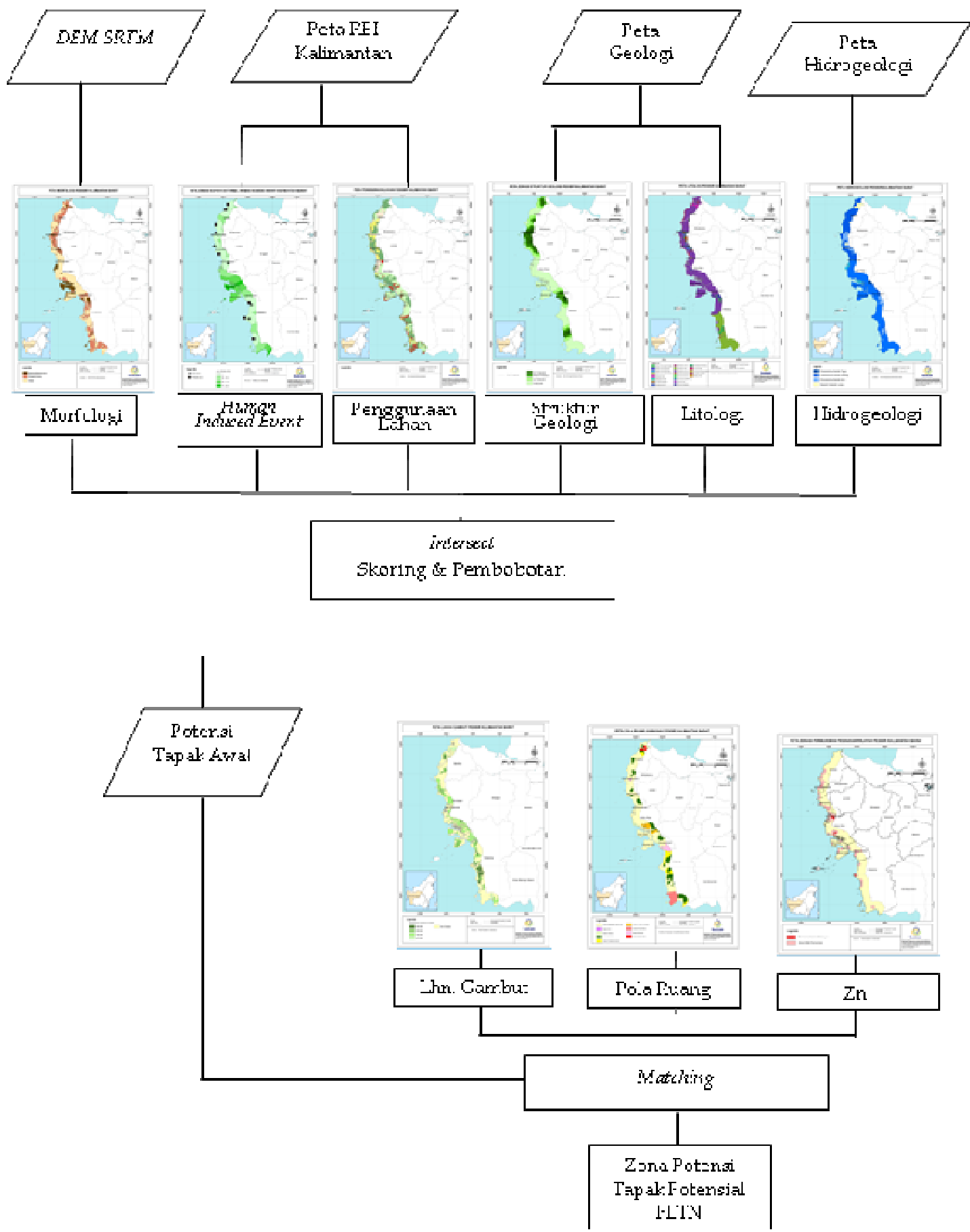

\section{Gambar 1. Diagram Alir Penelitian}

Peta-peta parameter pengaruh potensi penempatan tapak PLTN masing-masing memiliki nilai hirarkinya, setiap unit memiliki pengaruh yang berbeda-beda. Nilai tingkatan pengaruh tersebut diberikan skor. Tiap parameter akan memiliki nilai bobot yang berbedabeda. Parameter yang memiliki pengaruh besar diberikan faktor pembobot yang lebih tinggi. Metode Skoring yang dilakukan dengan faktor pembobot memiliki jenis metode Pembobotan Berjenjang Tertimbang. Parameter-parameter tersebut diantaranya adalah Peta Morfologi, Struktur Geologi, Litologi, Penggunaan Lahan, Peta Human Induced Event dan Peta Hidrogeologi. Diagram alir pengolahan data dilihat pada Gambar 1. 


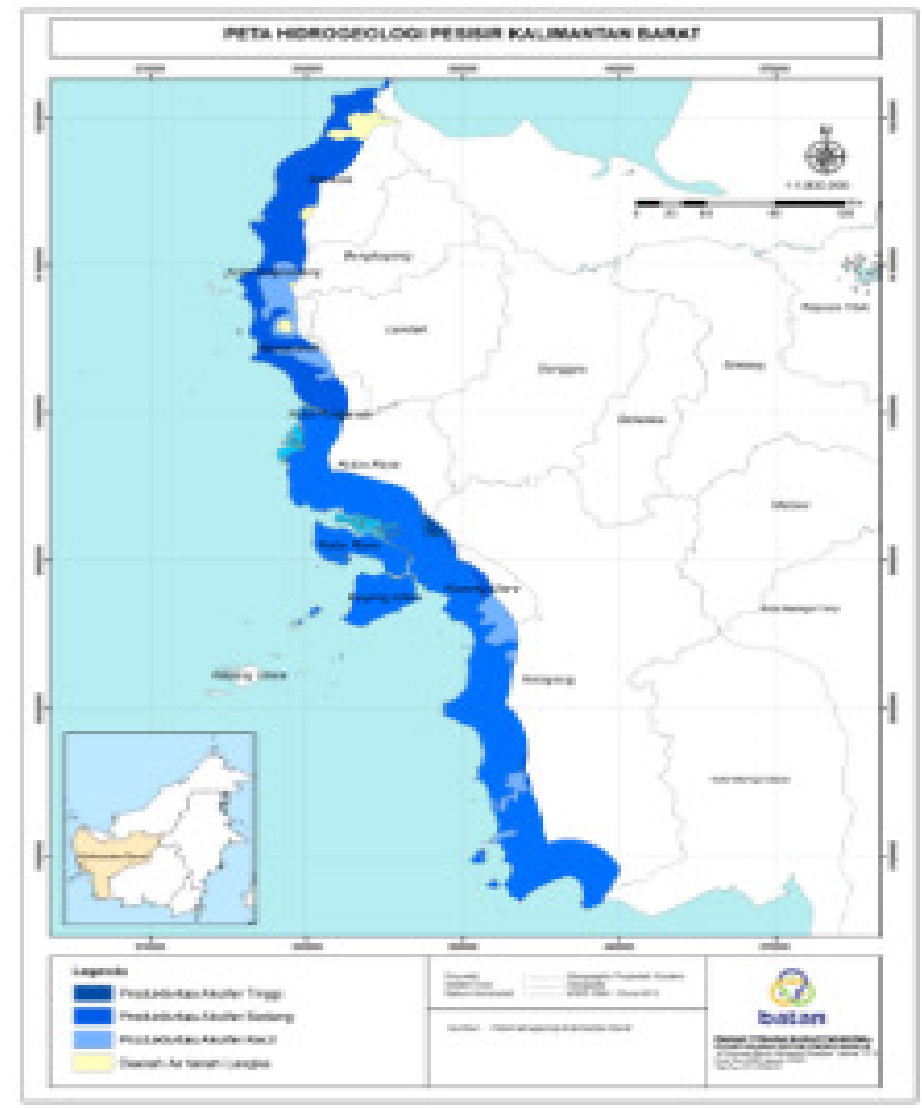

Gambar 2. Wilayah Studi di Pesisir Kalimantan Barat

\section{HASIL DAN PEMBAHASAN}

\subsection{Wilayah Penelitian}

Wilayah penelitian mengacu pada hasil pra-survei yang dilakukan sebelumnya pada tahun 2014 di kabupaten Ketapang dan Kayong Utara, propinsi Kalimantan Barat yang menghasilkan empat daerah interes dan pra-survei yang dilakukan di propinsi Kalimantan Barat pada tahun 2013 yang menghasilkan daerah interes di kabupaten Ketapang dan Kayong Utara. Kedua hasil pra-survei tersebut kemudian dijadikan sebagai acuan dalam penentuan wilayah studi yang mencakup wilayah sepanjang pesisir provinsi Kalimantan Barat. Gambaran wilayah studi dengan kedudukan daerah-daerah interes yang terbentang di sepanjang pesisir ditampilkan pada Gambar 2.

Secara umum, daerah penelitian merupakan wilayah dataran dan perbukitan rendah, dengan morfologi yang terbagi dalam 3 (tiga) satuan yaitu: (a) satuan morfologi bukit rendah yang menempati daerah sekitar kaki gunung dengan ketinggian sekitar $35-50 \mathrm{~m}$ dpl (di atas permukaan laut) dan satuan morfologi ini ditempati oleh satuan tanah laterit, (b) satuan morfologi dataran rendah yang menempati daerah sekitar kaki gunung dengan ketinggian $5-35 \mathrm{~m}$ dpl, dan satuan morfologi ini ditempati oleh satuan endapan aluvium, (c) satuan morfologi rawa yang menempati sepanjang pantai dan sebagian besar wilayah dengan ketinggian maksimal $25 \mathrm{~m} \mathrm{dpl}$, dan satuan batuan yang menempatinya adalah satuan endapan rawa ${ }^{[4]}$. Daerah sepanjang pantai dari Utara ke Selatan dan daerah aliran sungai merupakan dataran rawa-rawa, yaitu mulai dari Kecamatan di Kayong Utara, Matan Hilir Utara, Delta Pawan, Matan Hilir Selatan, dan Kendawangan 
Secara litologi beberapa endapan batuan yang dapat diamati di lapangan meliputi: (a) satuan endapan aluvium, terdapat di sekitar bagian tengah wilayah penelitian, terutama di sekitar poros jalan provinsi antara Sungai Gantang - Marau. Umumnya terdiri dari endapan lempung, pasir, dan kerikil, termasuk formasi endapan aluvial berumur holosen, (b) satuan endapan rawa, tersebar luas terutama di bagian utara, timur dan selatan wilayah penelitian, umumnya berupa lempung, lumpur, pasir halus dan sisa tumbuhan, termasuk formasi endapan rawa yang berumur Holosen, (c) satuan tanah laterit, terdapat di bagian barat daerah penelitian, umumnya terdiri dari hasil pelapukan batuan sedimen dari batuan kompleks Ketapang. Dataran rendah merupakan ciri khas bentuk bentang alam endapan gambut, yang menempati daerah yang luas dan meliputi bagian utama lembar peta di sepanjang wilayah penelitian.

\subsection{Tahap Pembuatan Peta Parameter dan Tahap Skoring \& Pembobotan Kesesuaian Lahan Tapak PLTN}

Pemodelan analisis kesesuaian lahan tapak PLTN dilakukan dengan tahapan pembuatan peta setiap parameter pengaruh potensi tapak PLTN yang meliputi: Peta Struktur Geologi, Peta Litologi, Peta Morfologi, Peta Hidrogeologi, Peta Human Induced Event (HIE), Peta Penggunaan Lahan, Peta Zonasi Permukiman, Peta Lahan Gambut dan Peta Pola Ruang Kalimantan Barat.

\subsubsection{Tahap Pemodelan (Intersect)}

Kelima parameter dilakukan teknik overlay melalui metode intersect. Hasil intersect memiliki unit-unit terkecil dan setelah itu dilakukan penggabungan nilai skoring dengan faktor pembobotnya. Unit-unit dengan nilai skor tertinggi merupakan unit-unit yang memiliki potensi sebagai tapak PLTN di Pesisir Kalimantan Barat. Skoring dan pembobotan dari masing-masing parameter dinyatakan pada Tabel 1, sedangkan klasifikasi dari skor dinyatakan pada Tabel 2.

Tabel 1. Skoring dan Pembobotan

\begin{tabular}{|c|c|c|c|c|}
\hline No & Parameter & Faktor Pembobot & Kriteria & Skor \\
\hline \multirow{4}{*}{1} & \multirow{4}{*}{ Stuktur Geologi } & \multirow{4}{*}{11} & Unfractured & 4 \\
\hline & & & Low Fractured & 3 \\
\hline & & & Medium Fractured & 2 \\
\hline & & & High Fractured & 1 \\
\hline \multirow{4}{*}{2} & \multirow{4}{*}{$\begin{array}{l}\text { External Human Induced } \\
\text { Event (Jarak terhadap } \\
\text { pusat-pusat fasilitas) }\end{array}$} & \multirow{4}{*}{9} & $>75 \mathrm{Km}$ & 4 \\
\hline & & & $50-75 \mathrm{Km}$ & 3 \\
\hline & & & $25-50 \mathrm{Km}$ & 2 \\
\hline & & & $<25 \mathrm{Km}$ & 1 \\
\hline \multirow{4}{*}{3} & \multirow{4}{*}{ Morfologi } & \multirow{4}{*}{8} & Datar & 4 \\
\hline & & & Bergelombang & 3 \\
\hline & & & Berbukit & 2 \\
\hline & & & Bergunung & 1 \\
\hline \multirow{4}{*}{4} & \multirow{4}{*}{ Lithologi } & \multirow{4}{*}{8} & Batuan Beku & 4 \\
\hline & & & Batuan Metamorf & 3 \\
\hline & & & Batuan Sedimen & 2 \\
\hline & & & Alluvium & 1 \\
\hline 5 & Penggunaan Lahan & 6 & Lahan Kosong & 4 \\
\hline
\end{tabular}




\begin{tabular}{cllc}
\hline No & Parameter & \multicolumn{1}{c}{ Faktor Pembobot } & Skor \\
\hline & & Semak Belukar/Tegalan & 3 \\
& & Lahan Perkebunan & 2 \\
& & Lahan Terbangun & 1 \\
\hline \multirow{3}{*}{ Hidrologi } & & $<5 \mathrm{~m}$ dari permukaan & 4 \\
& & $5-10 \mathrm{~m}$ dari permukaan & 3 \\
& 4 & $10-15 \mathrm{~m}$ dari permukaan & 2 \\
& & $>15 \mathrm{~m}$ atau tidak ada air & \\
& & tanah & 1
\end{tabular}

Tabel 2. Klasifikasi

\begin{tabular}{lcc}
\hline No & Skor Total & Klasifikasi \\
\hline 1 & $260-170$ & Potensi \\
2 & $<170$ & Tidak Berpotensi \\
\hline
\end{tabular}

\subsubsection{Tahap Matching}

Tahapan ini merupakan tahapan eliminasi dimana wilayah yang memiliki potensi akan dilakukan matching dengan mempertimbangkan faktor seperti lahan gambut, zonasi permukiman dan pola ruang kawasan pesisir Kalimantan Barat. Kriteria matching factor dinyatakan pada Tabel 3. Wilayah yang memiliki potensi namun merupakan wilayah dengan lahan gambut, dekat dengan pemukiman maupun pola ruangnya sudah ditetapkan sebagai kawasan yang tidak dapat dirubah peruntukannya akan langsung dieliminasi sebagai wilayah tidak berpotensi.

Tabel 3. Matching Factor

\begin{tabular}{lllc}
\hline No & Parameter & Kriteria & Hasil \\
\hline \multirow{2}{*}{ Lahan Gambut } & Gambut & Tidak \\
& Non-Gambut & Ya \\
\hline \multirow{2}{*}{2} & \multirow{2}{*}{ Zona Permukiman } & $\begin{array}{l}\text { Zona Permukiman Penduduk } \\
\text { Zona Non Permukiman Penduduk }\end{array}$ & $\begin{array}{c}\text { Tidak } \\
\text { Ya }\end{array}$ \\
\hline \multirow{3}{*}{3} & Kawasan Hutan Lindung & \\
& \multirow{2}{*}{ Pola Ruang / Status Lahan } & Kawasan Lindung Setempat & \multirow{2}{*}{ Tidak } \\
& & Kawasan Suaka Marga Satwa & \\
& & Kawasan Cagar Alam & Ya Taman Nasional \\
\hline
\end{tabular}

\subsection{Evaluasi Pembobotan dalam Pemilihan Tapak}

Pemilihan daerah tapak interest untuk lokasi PLTN sebagaimana yang telah ditetapkan dalam Peraturan Kepala Bapeten, didasarkan pada kriteria umum untuk tahap pra survei yang antara lain meliputi aspek: kebutuhan pasokan air pendingin, jumlah penduduk, jarak industri strategis yang menghasilkan bahan berbahaya, jarak jaringan perpipaan (minyak, dan gas), ketersediaan air tanah, jenis tutupan lahan bukan daerah rawa alamiah /genangan air sepanjang tahun, jarak terhadap pelabuhan udara (bandara) dan pelabuhan laut, jenis area kawasan lindung (cagar alam, suaka margasatwa, dan cagar budaya), serta jarak terhadap fasilitas militer terdekat.

Pada hasil sebelumnya untuk pemilihan tapak potensial PLTN diketahui bahwa tapak potensial pertama terdapat di Kecamatan Kendawangan, tapak potensial ke-2 di Kecamatan 
Sukadana yang merupakan wilayah di Kabupaten Kayong Utara, tapak potensial ke-3 dan ke-4, masing-masing di Kecamatan Matan Hilir Utara dan di wilayah Kecamatan Matan Hilir Selatan (Gambar 3).
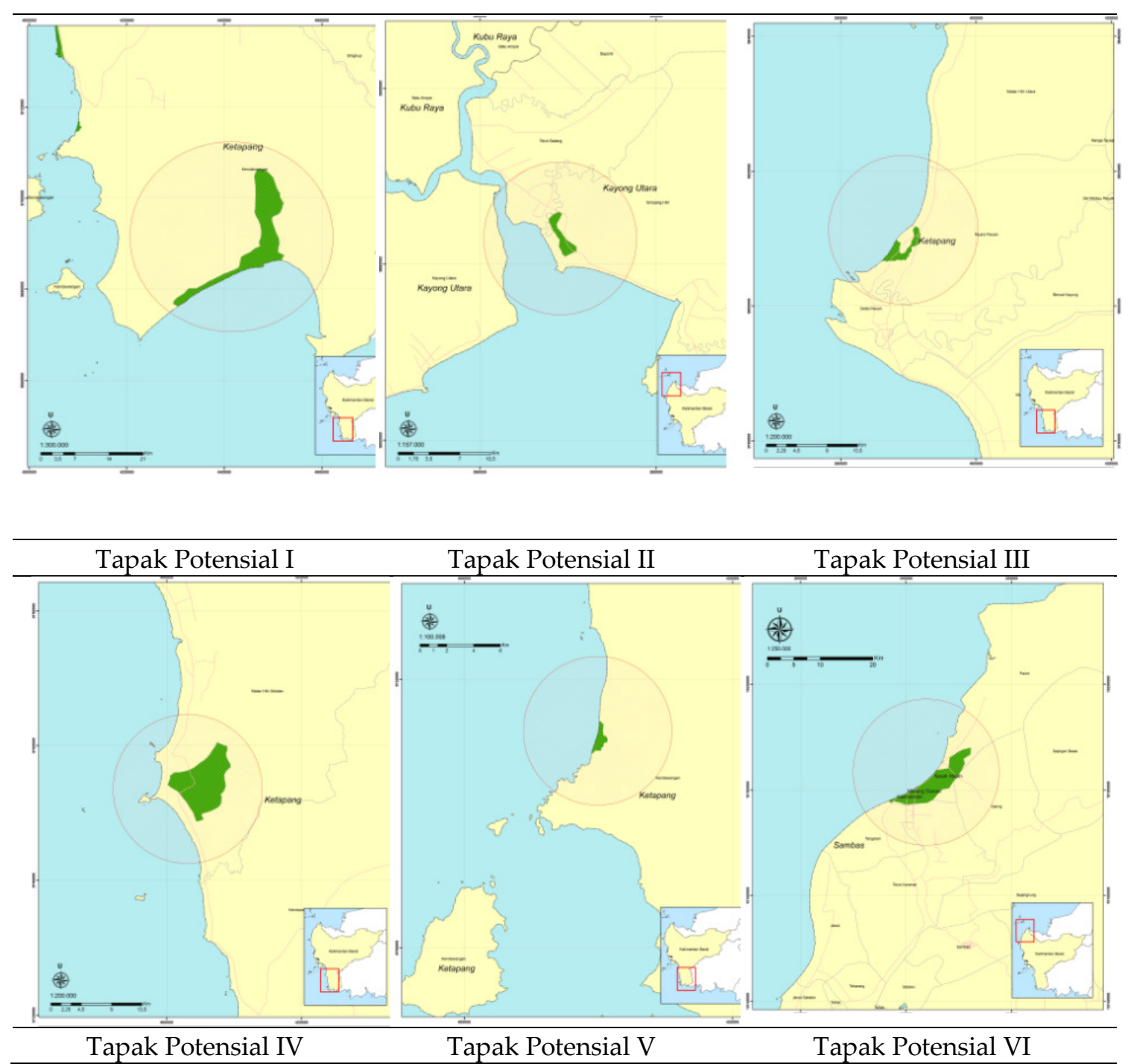

Gambar 3. Peta Sebaran Daerah Potensi Tapak PLTN per Wilayah Pesisir

Pada pengolahan data selanjutnya telah terjadi pergeseran tapak potensial. Hasil semula tapak potensial pertama berada di Kecamatan Kendawangan, pada pengolahan selanjutnya tapak potensial pertama yang mempunyai nilai tertinggi berada di Desa Air Besar, Kabupaten Ketapang.

Pada pengolahan data sebelumnya, pesisir Kalimantan Barat bagian Selatan yang berada di wilayah Air Hitam belum dipertimbangkan dalam analisis pemilihan tapak PLTN. Berdasarkan hasil penelitian dengan survei lapangan, dihasilkan kondisi litologi pada setiap tapak potensial terpilih, khususnya di daerah potensi 1 dan 2 yang mempunyai komposisi hampir sama[9]. Di Kecamatan Kendawangan terdapat batuan granit, vulkanik yang dapat berperan sebagai batuan keras yang dapat dipilih sebagai lokasi tapak PLTN (Gambar 4) ${ }^{[7,9]}$. 


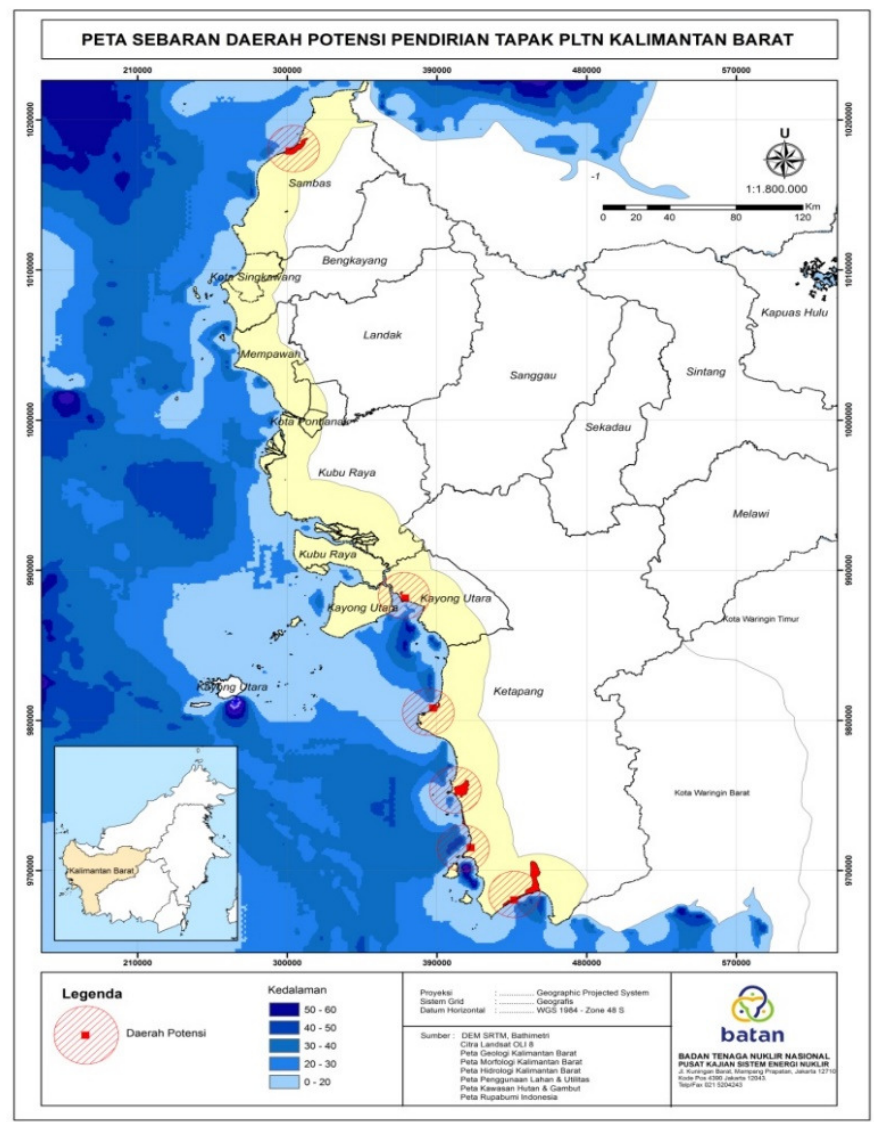

Gambar 4. Peta Tapak Potensial PLTN per Wilayah

Keterangan:

\begin{tabular}{|c|c|c|c|}
\hline Tapak Potensial & Nama Daerah & Koordinat & $\begin{array}{l}\text { Nilai } \\
\text { Skoring }\end{array}$ \\
\hline $\mathrm{I}$ & $\begin{array}{lccc}\text { Desa Air } & \text { Besar, } & \text { Kecamatan } \\
\text { Kendawangan, } & \text { Kabupaten Ketapang }\end{array}$ & $\begin{array}{c}X=436681 \\
Y=9681133\end{array}$ & 205 \\
\hline II & $\begin{array}{l}\text { Desa Sie, Kecamatan Simpang Hilir, } \\
\text { Kabupaten Kayong Utara }\end{array}$ & $\begin{array}{c}X=370210 \\
Y=9881837\end{array}$ & 190 \\
\hline III & $\begin{array}{l}\text { Desa Sungai Kanan, Kecamatan Muara, } \\
\text { Kabupaten Ketapang }\end{array}$ & $\begin{array}{c}X=387938 \\
Y=9807943\end{array}$ & 186 \\
\hline IV & $\begin{array}{l}\text { Desa Sungai Nanjung, Kecamatan Matan, } \\
\text { Kabupaten Ketapang }\end{array}$ & $\begin{array}{c}X=403171 \\
Y=9753043\end{array}$ & 185 \\
\hline $\mathrm{V}$ & $\begin{array}{l}\text { Desa Kendawangan Kanan, Kecamatan } \\
\text { Kendawangan, Kabupaten Ketapang }\end{array}$ & $\begin{array}{c}X=410126 \\
Y=9807943\end{array}$ & 181 \\
\hline VI & $\begin{array}{lcc}\text { Desa Matang, Kecamatan } & \text { Paloh, } \\
\text { Kabupaten Sambas } & & \\
\end{array}$ & $\begin{array}{c}X=302159 \\
Y=10179682\end{array}$ & 181 \\
\hline
\end{tabular}

Hasil interpretasi data citra SPOT untuk mendapatkan peta tutupan lahan dan selanjutnya di-overlay-kan terhadap tapak potensial yang telah diperoleh dapat dilihat pada Gambar 5. 


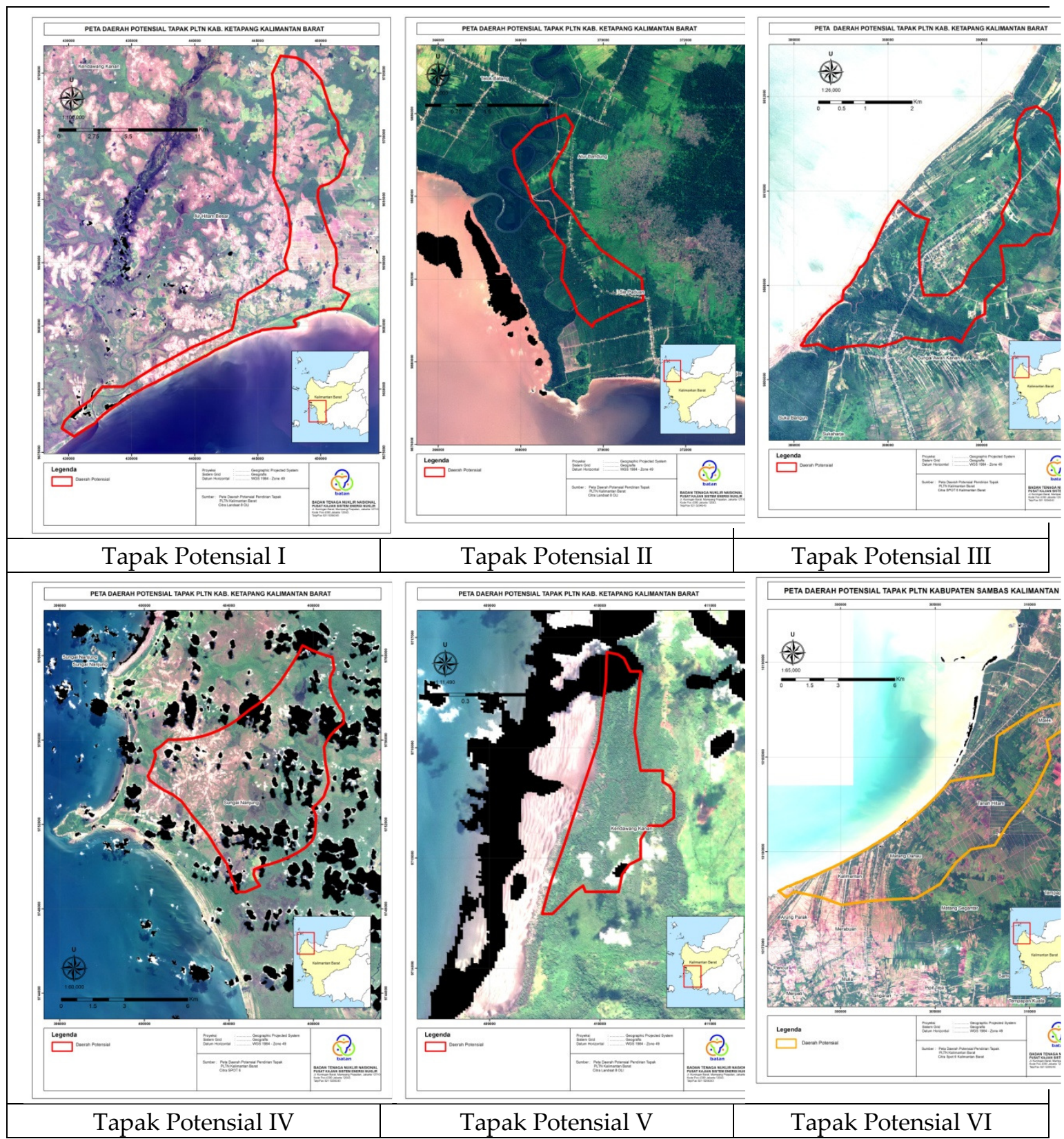

Gambar 5. Kesesuaian Tapak Potensial dengan Tutupan Lahan

Hasil overlay menunjukkan bahwa tutupan lahan tapak potensial 1 berada di kawasan lahan terbuka yang dari hasil survei lapangan diperoleh bahwa tapak potensial 1 berada di wilayah dengan kondisi permukaan tanah yang banyak mengandung pasir kuarsa. Tapak potensial 2 dari interpretasi data citra SPOT menunjukkan tutupan lahan berupa hutan dan sawah, tapak potensial 3 berada di tutupan lahan campuran dan lahan terbuka, tapak potensial 4 berada di kawasan tutupan lahan seperti tapak potensial 1, yaitu berada di kawasan lahan terbuka dengan permukaan tanahnya kebanyakan banyak mengandung pasir kuarsa. Sedangkan tapak potensial 5 dan 6 berada di kawasan dengan tutupan lahan terbuka dan juga lahan campuran. Jadi dari interpretasi data penginderaan jauh dan hasil pembobotan menunjukkan bahwa semua tapak potensial terpilih tidak berada di wilayah yang tidak direkomendasikan sebagai tapak PLTN. Namun demikian diperlukan studi lanjut yang lebih mendalam untuk mendapatkan tapak PLTN terpilih. 


\section{KESIMPULAN}

Hasil penelitian diperoleh tapak potensial secara berurutan, yaitu prioritas pertama di tapak Desa Air Besar Kecamatan Kendawangan Kabupaten Ketapang, selanjutnya tapak Desa Sie Kecamatan Simpang Hilir Kabupaten Kayong Utara, Desa Sungai Kanan, Kecamatan Muara Kabupaten Ketapang, Desa Sungai Nanjung Kecamatan Matan Kabupaten Ketapang, Desa Kendawangan Kanan Kecamatan Kendawangan Kabupaten Ketapang, dan prioritas terakhir adalah Desa Matang, Kecamatan Paloh, Kabupaten Sambas. Hasil analisis kesesuaian lahan berdasar pada interpretasi citra satelit resolusi tinggi menunjukkan bahwa kesemua tapak potensial yang telah terpilih (6 lokasi tapak potensial) tersebut telah memenuhi kriteria umum dan khusus dalam pelaksanaan pemilihan tapak potensial PLTN, diantaranya yaitu keberadaannya bukan di kawasan lindung maupun cagar alam, bukan merupakan kawasan gambut, serta jauh dari pemukiman.

\section{UCAPAN TERIMA KASIH}

Ucapan terimakasih ditujukan kepada Kapus PKSEN yang telah mengijinkan pelaksanaan penelitian; Dr. Hil Gendoet Hartono dari STTNAS yang telah membantu deskripsi batuan volkanik, Yogyakarta, Arif Ismail dan Adianto yang membantu dalam pengolahan data spasial maupun interpretasi citra satelit; Dinas ESDM, Dinas PU, dan BAPPEDA Kabupaten Ketapang yang telah membantu kelancaran penelitian; Dr. Sudi Ariyanto, M.Eng., staf Bidang KDT yang membantu pengambilan data.

\section{DAFTAR PUSTAKA}

[1]. SUDRAJAT, J., "Potensi dan Problematika Pembangunan Wilayah Pesisir di Kalimantan Barat", Jurnal Social Economic of Agriculture, Volume 2, Nomor I, Univesitas Tanjungpura, Pontianak, April 2013.

[2]. Pemerintah Provinsi Kalimantan Barat tahun 2013, RPJMD (Rencana Pembangunan Jangka Menengah Daerah Provinsi Kalimantan Barat tahun 2013-2018), 2013.

[3]. HENI SUSIATI, "Penentuan Tapak Potensial PLTN dengan Metode SIG di Wilayah Pesisir Provinsi Kalimantan Barat", Jurnal Pengembangan Energi Nukl;ir Volume 16, Nomor 2, Jakarta, Desember 2014.

[4]. BAPETEN, Perka BAPETEN No. 5 tahun 2007 tentang "Ketentuan Keselamatan Evaluasi Tapak Reaktor Nuklir", BAPETEN, Jakarta, 2007.

[5]. IAEA, Safety Standards Series No. NS-R-3. Safety Requirements. Vienna "Site Evaluation for Nuclear Installations". International Atomic Energy Agency. Vienna, 2003.

[6]. IAEA, "Site Survey and Site Selection for Nuclear Installation", Draft Specific Safety Guide No. SSG DS 433, Vienna, Austria: International Atomic Energy Agency. Austria, 2013.

[7]. PEMDA KABUPATEN KETAPANG, "Kajian Lingkungan Hidup Strategis", Pemda Kabupaten Ketapang, 2013.

[8]. EPRI, Final Report Siting Guide: "Site Selection and Evaluation Criteria for an Early Site Permit Application", EPRI. March 2002.

[9]. SUSIATI, H. dan MELLAWATI, J., “Evaluasi Data Dukung Lingkungan dalam Pemilihan Lokasi Tapak PLTN di Kabupaten Ketapang, Kalbar", Prosiding Seminar Nasional Teknologi Energi Nuklir 2014, Pontianak, 2014.

[10]. BETA PATRIA, I., "Evaluasi Daya Dukung Lingkungan Zona Industri Genuk, Semarang", Tesis Program Magister Ilmu Lingkungan Program Pasca Sarjana, Universitas Diponegoro, Semarang, 2008. 
[11]. SUDANA D., DJAMAL B., dan SUKIDO, "Geologi Lembar Kendawangan, Kalimantan", Lembar 1413, Skala 1:250.000, Departemen Pertambangan dan Energi, Direktorat Jendral Geologi dan Sumberdaya Mineral, Pusat Penelitian dan Pengembangan Geologi, 1994.

[12]. ZULFIKAR, HERRY RE., WASTONI C.P., DJADJA T., “Endapan Zirkon di Daerah Pangkalan Batu Kecamatan Kendawangan, Kabupaten Ketapang, Provinsi Kalimantan Barat", Prosiding Pemaparan Hasil-Hasil Kegiatan Lapangan dan Non Lapangan Tahun 2008, Pusat Sumber Daya Geologi, Bandung, 2008.

[13]. DE KEYSER F. \& RUSTANDI E., “Geologi Lembar Ketapang, Kalimantan”, Lembar 1414, Skala 1:250.000, Departemen Pertambangan dan Energi, Direktorat Jendral Geologi dan Sumberdaya Mineral, Pusat Penelitian dan Pengembangan Geologi, Bandung, 1993. 